\title{
Down Regulation of Protein Kinase C in Neuronal Cells: Effects on Neurotransmitter Release
}

\author{
Heinrich J. G. Matthies, H. Clive Palfrey, Lane D. Hirning, and Richard J. Miller \\ Department of Pharmacological and Physiological Sciences, University of Chicago, Chicago, Illinois 60637
}

We investigated the effects of phorbol esters on protein kinase $C$ (PKC) activity and on neurotransmitter release from cultured neuronal cells. Both differentiated and undifferentiated PC12 pheochromocytoma cells contained high levels of protein PKC. Under normal conditions all the enzyme activity was found in the cytoplasm. Addition of the phorbol esters phorbol 12-myristate-13-acetate (TPA) or phorbol 12,13-dibutyrate (PDBu) caused a rapid translocation of PKC from the cytoplasm to the particulate fraction. Continued culture of cells with these phorbol esters resulted in the decline of total PKC activity. After 10-20 hr of culture, both membrane and cytoplasmic PKC activity had declined to background levels. CAMP-dependent and $\mathrm{Ca}^{2+} /$ calmodulindependent protein kinase activities were only slightly affected by chronic phorbol ester treatment. Addition of active phorbol esters to PC12 cells produced an enhancement of the depolarization-induced release of ${ }^{3} \mathrm{H}$-norepinephrine. Following chronic phorbol ester treatment, the ability of these substances to enhance evoked catecholamine release was lost. Furthermore, depolarizing stimuli released considerably less ${ }^{3} \mathrm{H}$-norepinephrine than in control untreated cells. Phorbol esters also enhanced depolarization-induced ${ }^{3} \mathrm{H}$ norepinephrine release from primary cultures of rat sympathetic neurons. Chronic treatment of these neurons with phorbol esters also resulted in the loss of their ability to enhance transmitter release and in a large reduction in the extent of depolarization-evoked transmitter release. ChronIc phorbol ester treatment also resulted in the disappearance of PKC from sympathetic neurons, but had little effect on CAMP-dependent or $\mathrm{Ca}^{2+} /$ calmodulin-dependent kinase activities. These results demonstrate that PKC-deficient neurons can be prepared. The data also demonstrate that depolarization-induced neurotransmitter release is mediated by both protein kinase $\mathrm{C}$-dependent and independent pathways.

Protein kinase C (PKC) is found in high concentrations in the nervous system (Kikkawa et al., 1982; Nishizuka, 1986). As in other tissues, activation of $\mathrm{PKC}$ in neuronal tissues, using drugs

Received Aug. 12, 1986; revised Oct. 16, 1986; accepted Oct. 24, 1986.

This work was supported by PHS Grants DA-02121, DA-02575, MH-40165 (R.J.M.), GM-33546 (H.C.P.), and grants from the University of Chicago Brain Research Institute, Miles Inc., Sterling-Winthrop Inc., and The Chicago Heart Association. R.J.M. is a Guggenheim Fellow.

Correspondence should be addressed to Professor Richard J. Miller, Department of Pharmacological and Physiological Sciences, University of Chicago, 947 E. 58th Street, Chicago, IL 60637.

Copyright (c) 1987 Society for Neuroscience $0270-6474 / 87 / 041198-09 \$ 02.00 / 0$ such as phorbol esters, results in a very large number of effects. These include changes in neuronal development (Pahlman et al., 1981; Akerman et al., 1984; Montz et al., 1985), the modification of ion channels (Baraban et al., 1985; De Riemer et al., 1985b; Alkon et al., 1986; Di Virgilio et al., 1986; Madison et al., 1986; Malenka et al., 1986a, b; Strong et al., 1986) and receptors (Francel et al., 1986; Liles et al., 1986), alterations in neurotransmitter synthesis (Wang et al., 1986) and release (Pozzan et al., 1984; Harris et al., 1985; Publicover, 1985; Zurgil and Zisapel, 1985; Eusebi et al., 1986), and changes in synaptic plasticity (Akers et al., 1986; Malenka et al., 1986a). Such effects of phorbol esters suggest a role for $\mathrm{PKC}$ in the normal control of these processes. Clearly activation of $\mathrm{PKC}$ with phorbol esters has been of central importance in implicating the enzyme in these various cellular events.

In order to further define the roles of $\mathrm{PKC}$, it would be useful to be able to inhibit the enzyme in situ in a routine manner. There have been several attempts to produce specific PKC antagonists (Hidaka et al., 1984; Kawamoto and Hidaka, 1984). However, although it can be demonstrated that a number of agents will block PKC, they are of low potency and poor specificity (Mazzei et al., 1982; Wooten and Wrenn, 1984; De Riemer et al., 1985a). For example, PKC can be inhibited by phenothiazines, but the same drugs also block $\mathrm{Ca}^{2+} /$ calmodulindependent protein kinase activity at least as well (De Riemer et al., 1985a).

An alternative approach to this problem would be the preparation of PKC-deficient cells. This has been realized in the case of a number of non-neuronal tissues by chronic phorbol ester treatment. PKC normally resides in the cytoplasm (Nishizuka, 1986). When activated by diacylglycerol (DAG) or a phorbol ester, the enzyme rapidly translocates to the cell membrane to which it binds with high affinity (Kraft and Anderson, 1983; Palfrey and Waseem, 1985; Wolf et al., 1985; Guy et al., 1986; Liles et al., 1986; McArdle and Conn, 1986). Extended treatment with phorbol esters leads to a decline in total PKC activity, eventually to undetectable levels (Yamasaki et al., 1980; Jaken et al., 1981; Solanki et al., 1981; Yamasaki et al., 1982; Collins and Rozengurt, 1984; Rodriguez-Pena and Rozengurt, 1984; Ashendel, 1985; Ballester and Rosen, 1985; Wickremansinghe et al., 1985; Fabbro et al., 1986; Glynn et al., 1986; Muldoon et al., 1987). In order to further pursue our investigations into the roles of PKC in neuronal function, we have analyzed the effects of chronic phorbol ester treatment on PKC activity in a nerve-related clonal cell line (PC12) and in primary cultures of rat sympathetic neurons. Our results indicate that PKC-deficient neurons can be conveniently prepared, and also suggest a role for $\mathrm{PKC}$ in the normal control of stimulus-secretion coupling. 


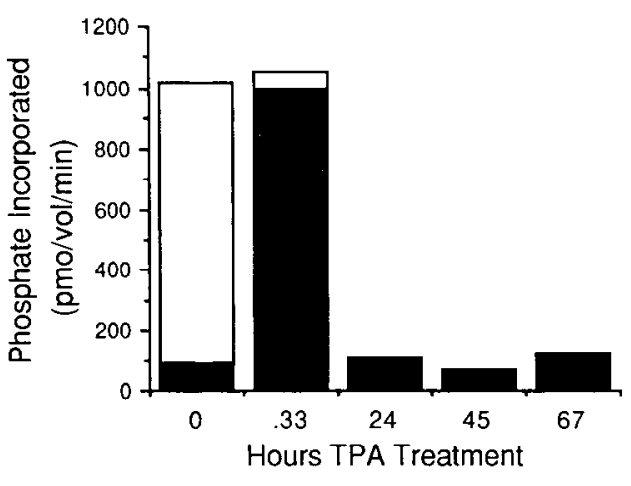

Figure 1. Time course of the effect of phorbol ester on particulate and cytosolic PKC activity. Cells were incubated with $1 \mu \mathrm{M}$ TPA for the times indicated. The results are means of duplicate assays. $\square$, Cytosolic PKC activity. Particulate PKC activity. PKC was assayed as in Materials and Methods. Control PKC-specific activity was 88 pmol phosphate incorporated per milligram of protein per minute (particulate) and 467.5 pmol phosphate incorporated per milligram of protein per minute (cytosol).

\section{Materials and Methods}

Materials. ${ }^{3} \mathrm{H}-\mathrm{Norepinephrine}(43.9 \mathrm{Ci} / \mathrm{mmol})$ and ${ }^{3} \mathrm{H}$-phorbol-12,13dibutyrate $(15.8 \mathrm{Ci} / \mathrm{mmol})$ were obtained from New England Nuclear, $\gamma^{32}$ P-ATP from Amersham. Phosphocellulose paper was from Whatman. Phorbol esters, norepinephrin, pargyline, ascorbate, histone $\mathrm{Hl}$ and $\mathrm{f} b$ were purchased through Sigma Chemical Co. Synapsin I was purified from bovine brain as previously described (Palfrey et al., 1983). All other chemicals were obtained from local chemical suppliers and were of reagent grade.

Cell culture. PC12 rat pheochromocytoma cells were cultured as described (Greene and Tischler, 1976; Toll, 1982) with slight modifications. PC1 2 cells were cultured in Dulbecco's modified Eagle's medium (DMEM; Gibco) supplemented with $10 \%(\mathrm{vol} / \mathrm{vol})$ heat-inactivated horse serum (Hazelton KC Biological), 5\% (vol/vol) fetal bovine serum (Hazelton KC Biological), penicillin-streptomycin $(100 \mathrm{U} / \mathrm{ml}$ and $100 \mu \mathrm{g} /$ $\mathrm{ml}$, respectively; Gibco), and glutamine ( $2 \mathrm{~mm}$; Gibco). For release studies, cells were subcultured onto 12-well tissue culture plates (Costar) which were coated with rat tail collagen (Bornstein, 1958). Cells were differentiated by growing them in the presence of $1 \mathrm{mM}$ dibutyryl cAMP (Sigma) and $50 \mathrm{ng} / \mathrm{ml}$ of NGF (7S NGF; Sigma) for about 2 weeks (Heidemann et al., 1985; Kongsamut and Miller, 1986). For phosphorylation experiments, cells were grown on $100 \mathrm{~mm}$ collagen-coated plates.

Sympathetic neurons were cultured from superior cervical ganglia (SCG) taken from 1-3-day-old rats (Perney et al., 1986). Cells were dissociated from ganglia essentially as described in Yamamoto et al. (1981), except that a mixture of collagenase $(0.1 \mathrm{U} / \mathrm{ml}) /$ dispase $(0.8$ $\mathrm{U} / \mathrm{ml}$ ) was used instead of collagenase alone. The sympathetic neural cells from 2-3 ganglia were plated in $0.5 \mathrm{ml}$ on $16 \mathrm{~mm}$ collagen-coated wells. The plating media and culture conditions were the same as those used in other studies (Hawrot and Patterson, 1979). Exposure to Ara C (Perney et al., 1986) resulted in preparations that were essentially free of fibroblasts and other non-neuronal cells.

${ }^{3} \mathrm{H}$-norepinephrine release assays. $\mathrm{PC1} 2$ release assays were performed according to previously published methods (Kongsamut and Miller, 1986). Briefly, cells were loaded with $0.5 \mathrm{ml}$ of media containing $6 \mu \mathrm{M}{ }^{3} \mathrm{H}$-norepinephrine (NE; sp. act., $1.65 \mu \mathrm{Ci} / \mathrm{ml}$ ) for $1-2 \mathrm{hr}$ at $37^{\circ} \mathrm{C}$ in a HEPES-buffered assay medium (Shalaby et al., 1984). Cells were then washed using 8 successive rinses with $0.5 \mathrm{ml}$ of buffer in a shaking water bath at $37^{\circ} \mathrm{C}$. Release was then quantitated by replacing the medium in the wells every 4 min and collecting the entire $0.5 \mathrm{ml}$ for liquidscintillation counting. Release was elicited in the third fraction by 70 $\mathrm{mM} \mathrm{K} \mathrm{K}^{+} . \mathrm{Na}^{+}$and $\mathrm{K}^{+}$replaced each other reciprocally. Drugs were included as indicated. Cells were then extracted with $0.2 \%$ SDS to determine the radioactivity remaining in the cells. Release was expressed as a percentage of radioactivity present in the cells prior to the $\mathrm{K}^{+}$-induced release. Basal release varied from 1 to $3 \%, \mathrm{~K}^{+}$-induced release from 12 to $30 \%$, and phorbol ester-induced release from 15 to $45 \%$ of the total labeled pool.

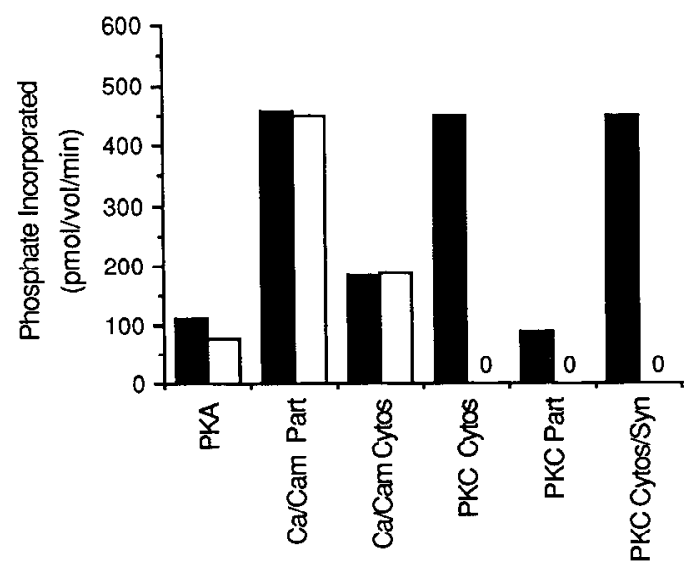

Figure 2. Effect of chronic phorbol ester treatment on the activities of various kinases in PC12 cells. Cells were cultured with $1 \mu \mathrm{M}$ TPA for $24 \mathrm{hr}$. Enzymes were assayed as in Materials and Methods. Part, particulate; Cytos, cytosolic; Syn, assay using Synapsin I as exogenous substrate. $\square$, Control activity. $\square$, TPA-treated.

Sympathetic neuron release assays were performed as outlined in Perney et al. (1986), that is, essentially as for PC12 cells with minor modifications. Sympathetic cells on day 5 or 6 after plating were used. Incubation with $2 \mu \mathrm{M}{ }^{3} \mathrm{H}-\mathrm{NE}$ lasted $1 \mathrm{hr}$ and was followed by 4 washes over a $10 \mathrm{~min}$ period and then 4 more 5 min rinses. The next 5 changes of buffer were then collected and counted. The third solution contained $70 \mathrm{~mm} \mathrm{~K} \mathrm{~K}^{+}$. Drugs were added as indicated. Cells were extracted and release was quantitated as for PC12 cells.

In vitro phosphorylation. $\mathrm{PC} 12$ cells were grown on $100 \mathrm{~mm}$ collagencoated plates and SCG sympathetic cells on $60 \mathrm{~mm}$ collagen-coated plates for 5-6 d. After the appropriate pretreatment with phorbol esters, cells were washed 3 times with Tris-buffered saline and then scraped with a rubber policeman. Cells were pelleted $(1000 \times g$ for $5 \mathrm{~min})$, resuspended in at least a 10-fold excess of homogenization buffer [25 mм Tris, $\mathrm{pH}$ 7.5, $5 \mathrm{~mm}$ 2-mercaptoethanol, $1 \mathrm{~mm}$ EDTA, $0.5 \mathrm{~mm}$ EGTA, 0.1 mM phenylmethylsulfonyl fluoride (PMSF), $0.02 \mathrm{~mm}$ leupeptin], sonicated briefly (10 sec; setting 1-2, 50\% output Branson 200) and centrifuged at low speed to remove nuclei and debris. To generate cytosolic and particulate fractions, the low-speed supernatant was spun at $120,000 \times g$ for $30 \mathrm{~min}$ in an ultracentrifuge. The pellet (particulate fraction) was resuspended in homogenization buffer (typically one-half the initial homogenate volume) by being passed 3-4 times through a 27-gauge needle or by brief sonication. Protein determinations (Biorad assay) were made. Both fractions were then diluted with $2 \%$ NP40 to give a final concentration of $0.2 \%$ NP40. Samples were now incubated for at least $30 \mathrm{~min}$ at $4^{\circ} \mathrm{C}$. This protein solution was then again diluted approximately 10 -fold to give $25-50 \mu \mathrm{g} / \mathrm{ml}$ in the final assay. PKC activity was assessed as in Palfrey and Waseem (1985). Samples, 2.5$5 \mu \mathrm{g}$, were assayed in a final volume of $100 \mu \mathrm{l}$, containing $50 \mathrm{~mm}$ Tris$\mathrm{HCl}, \mathrm{pH} 7.4,5 \mathrm{mM} \mathrm{MgSO}, 1 \mathrm{~mm}$ EGTA or $0.5 \mathrm{mM} \mathrm{Ca}^{2+}, 50 \mu \mathrm{g} / \mathrm{ml}$ phosphatidyl serine, $0.2 \mathrm{mg} / \mathrm{ml}$ histone $\mathrm{H} 1$, and $50 \mu \mathrm{M} \gamma^{32} \mathrm{P}$-ATP $(100$ $500 \mathrm{mCi} / \mathrm{mmol}$ ). $\mathrm{Ca}^{2+} / \mathrm{calmodulin}$-dependent protein kinase assays were carried out in a final volume of $100 \mu l$, containing $50 \mathrm{~mm}$ Tris, pH 7.4, $1 \mathrm{mM}$ EGTA or $0.5 \mathrm{mM} \mathrm{Ca}{ }^{2+}$ plus $0.02 \mathrm{mg} / \mathrm{ml}$ calmodulin, $0.2 \mathrm{mg} / \mathrm{ml}$ Synapsin I, and $50 \mu \mathrm{M} \gamma^{32}$ P-ATP (Palfrey et al., 1983). Peptide mapping of phosphorylated Synapsin I revealed that $>90 \%$ of the $\mathrm{Ca}^{2+} / \mathrm{calmo-}$ dulin-stimulated incorporation occurred in a fragment of $M_{\mathrm{r}} 35,000$, indicating that we were measuring primarily CaM-kinase II activity. cAMP-dependent protein kinase was assayed according to the method of Walter et al. (1977). Assays were performed in a final volume of 100 $\mu$, containing $50 \mathrm{~mm}$ Tris, pH 7.5, $10 \mathrm{~mm} \mathrm{MgSO}_{4}, 1 \mathrm{~mm}$ EGTA, 0.2 $\mathrm{mg} / \mathrm{ml}$ histone $\mathrm{f} 2 \mathrm{~b}, 20 \mu \mathrm{M} 8 \mathrm{BrcAMP}$, and $50 \mu \mathrm{M} \gamma^{32} \mathrm{P}$-ATP. In samples lacking 8BrcAMP, $5 \mu \mathrm{g} / \mathrm{ml}$ Walsh inhibitor was added as indicated. All assay mixtures were preincubated for $1 \mathrm{~min}$ at $30^{\circ} \mathrm{C}$ and initiated by addition of ATP. The reactions for PKC and calcium/calmodulin-dependent kinase were terminated by the addition of an SDS sample buffer after $1 \mathrm{~min}$. cAMP-dependent protein kinase assays were terminated by the addition of a $50 \mathrm{~mm}$ EDTA/5 mM ATP stop solution after 2-5 min. In phosphorylation assays stopped by SDS-containing buffers, 


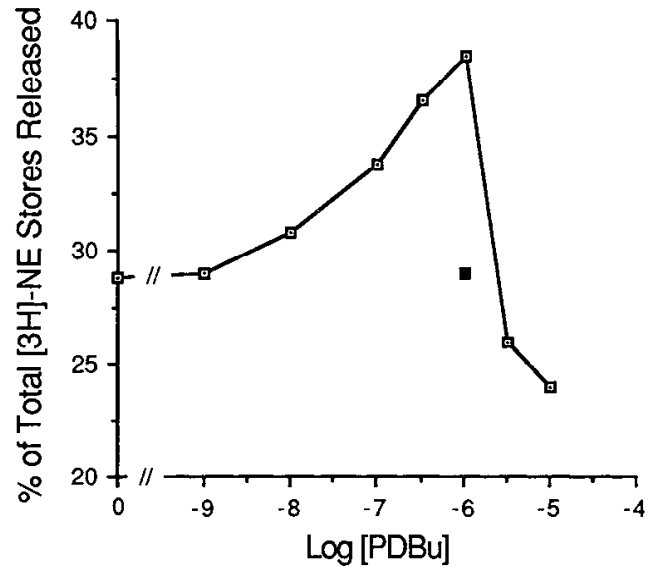

Figure 3. Dose-response curve illustrating the acute effects of $\mathrm{PDBu}$ on depolarization-induced release of ${ }^{3} \mathrm{H}-\mathrm{NE}$ from PC1 2 cells. Cells were pretreated with PDBu for $8 \mathrm{~min}$ and then for a further $4 \mathrm{~min}$ during stimulation with $70 \mathrm{mM} \mathrm{K}^{+}$. Some cells were also treated with the inactive phorbol ester $4 \alpha \mathrm{PDD}(1 \mu \mathrm{M})$. ๑, PDBu. $14 \alpha \operatorname{PDD}(1 \mu \mathrm{M})$. Points represent the means of 4 incubations.

phosphorylation of substrate was assessed using SDS-7.5\% PAGE, cutting out the appropriate substrate bands, followed by liquid-scintillation counting. Samples stopped by EDTA/ATP werc blottcd on to $1.2 \times$ $2.1 \mathrm{~cm}$ phosphocellulose paper squares (Whatman P81) and washed with water for 20 min prior to counting. Results are expressed in activity units $(\mathrm{pmol} / \mathrm{vol} / \mathrm{min})$, where the volume referred to is the "equivalent volume" of cytosol or membrane (so that the values may be quantitatively compared). In our experiments these volumes were equivalent to $2.5-5 \mu \mathrm{g}$ protein for both cytosol and membranes.

\section{Results}

Effects of chronic phorbol ester treatment on protein kinase $C$ activity in $\mathrm{PC} 12$ cells

We began our studies by using the rat pheochromocytoma cell line PC12. These cells contained high concentrations of PKC activity (Fig. 1). This activity was normally associated with the cell cytoplasmic fraction, but a small amount of histone kinase activity was associated with the particulate fraction under control conditions. Cells differentiated with NGF contained 5-10fold higher specific activity than those found in undifferentiated cells. In differentiated PC12 cells, virtually all the enzyme activity was also found in the cytoplasm. We next examined the effect of phorbol ester treatment on the distribution of PKC activity in undifferentiated and differentiated PC1 2 cells. Following the addition of phorbol 12-myristate-13acetate (TPA) or phorbol-12,13-dibutyrate (PDBu) to the incubation medium, there was a rapid and complete translocation of PKC activity from the cytoplasm to the particulate fraction (Fig. 1). This occurred in both differentiated and undifferentiated PC1 2 cells. In the continued presence of phorbol esters, $\mathrm{PKC}$ activity associated with the particulate fraction declined, such that after several hours it had essentially returned to control levels. While particulate PKC activity was declining, cytoplasmic PKC activity remained low, indicating that $\mathrm{PKC}$ was not merely returning to the cytoplasm from the membrane. Longterm treatment of both differentiated and undifferentiated PC12 cells led to a similar depletion of PKC activity. Phorbol esters that are ineffective as activators of PKC (e.g., $4 \alpha$ phorbol-12,13didecanoate; $4 \alpha \mathrm{PDD}$ ) did not cause enzyme translocation or down regulation. Similar results were obtained when another

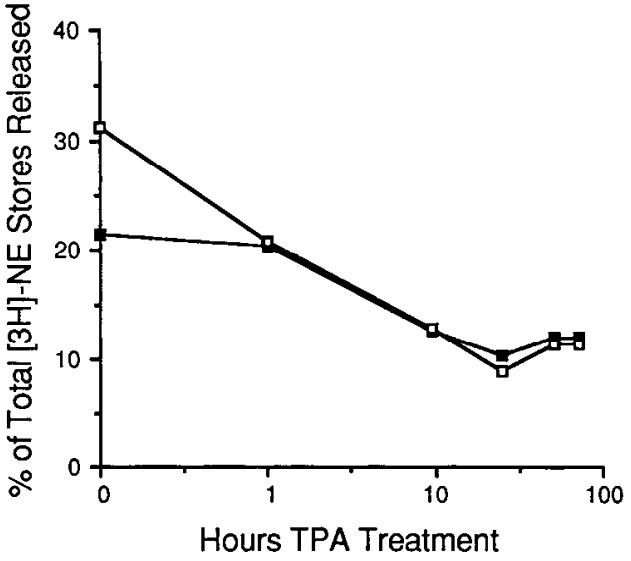

Figure 4. Time course of the effect of TPA $(1 \mu \mathrm{M})$ on the evoked release by ${ }^{3} \mathrm{H}-\mathrm{NE}$ from PC1 2 cells. Cells were incubated with TPA $(1 \mu \mathrm{M})$ for the times indicated. TPA was now removed by extensive washings ( 60 min with TPA-free incubation medium, then $30 \mathrm{~min}$ with TPA-free medium containing $1 \%$ fatty acid-free BSA; see Fig. 6). Cells were now challenged with $70 \mathrm{~mm} \mathrm{~K} \mathrm{~K}^{+}$-containing medium with ( $\square$ ) or without $(\square)$ TPA (100 nM). Points represent the means of 4 incubations.

exogenous substrate, Synapsin I, was used instead of histone (Fig. 2). We also examined the effect of chronic phorbol ester treatment on cAMP-dependent and $\mathrm{Ca}^{2+} /$ calmodulin-dependent protein kinase activities. Under conditions in which PKC activity was entirely depleted from PC12 cells, there was little change in the activities of these other 2 protein kinases (Fig. 2), which indicated specificity in the effects of phorbol esters on protein phosphorylation systems.

\section{Effects of chronic phorbol ester treatment on evoked catecholamine release from $\mathrm{PC} 12$ cells}

We have previously identified 2 effects of $\mathrm{PKC}$ activation in PC1 2 cells (Harris et al., 1985). The first of these is the inhibition of voltage-sensitive $\mathrm{Ca}^{2+}$ influx. This observation has been confirmed in other laboratories (Di Virgilio et al., 1986; Messing et al., 1986) and has also been demonstrated in sensory neurons (Rane and Dunlap, 1986). The second action is the enhancement of voltage-dependent catecholamine release. Similar enhancement of evoked transmitter release by phorbol esters has also been reported in other systems (Pozzan et al., 1984; Harris et al., 1985; Publicover, 1985; Zurgil and Zisapel, 1985; Eusebi et al., 1986). We used this action of phorbol esters in PC12 cells as a bioassay to assess the functional consequences of PKC down regulation. Figure 3 illustrates how acute phorbol ester treatment enhanced the depolarization-induced release of ${ }^{3} \mathrm{H}-\mathrm{NE}$ from PC1 2 cells by about $30 \%$. At very high concentrations of phorbol ester $(>1 \mu \mathrm{M})$, an inhibitory effect was observed. Phorbol esters that are inactive as stimulators of PKC did not enhance release (see also Harris et al., 1985). We next treated PC1 2 cells with active phorbol esters (TPA or PDBu) for increasing periods of time. Cells were then washed very thoroughly to remove any drug (see below) and challenged with $70 \mathrm{mM} \mathrm{K}^{+}$or a $70 \mathrm{~mm}$ $\mathrm{K}^{+}$-phorbol ester combination. As the period of phorbol ester treatment increased, there were 2 major effects (Fig. 4). First, the ability of phorbol esters to enhance the evoked release of ${ }^{3} \mathrm{H}-\mathrm{NE}$ was lost; and second, the ability of a $70 \mathrm{mM} \mathrm{K} \mathrm{K}^{+}$depolarizing stimulus alone to release ${ }^{3} \mathrm{H}-\mathrm{NE}$ steadily declined over the treatment period. Ultimately, $70 \mathrm{mM} \mathrm{K}^{+}$released only about half as much ${ }^{3} \mathrm{H}-\mathrm{NE}$ in treated cells as in the control. The actual 


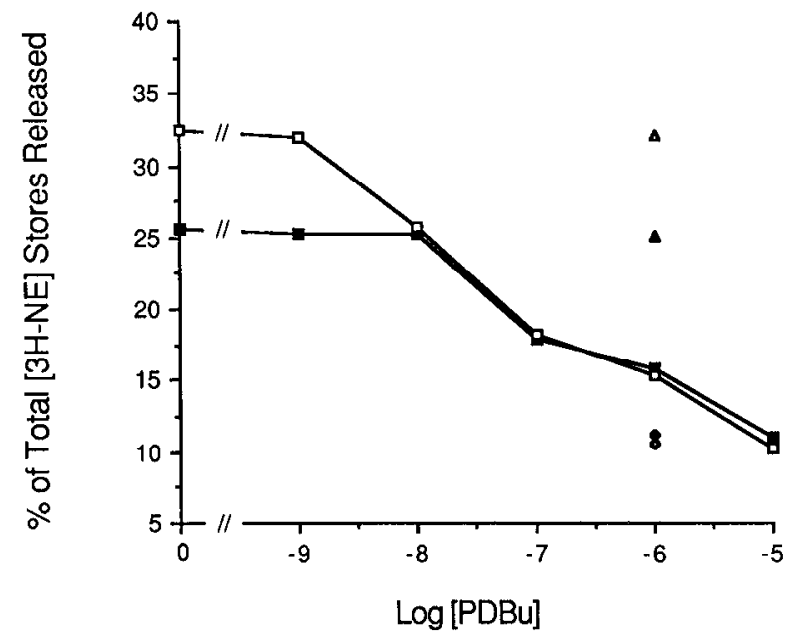

Figure 5. Dose-response curves illustrating the effects of chronic PDBu treatment on $70 \mathrm{mM} \mathrm{K}^{+}$-induced ${ }^{3} \mathrm{H}$-NE release from $\mathrm{PC} 12$ cells. Cells were treated with PDBu at the concentrations indicated for $24 \mathrm{hr}$. The phorbol ester was then washed out (see Figs. 4, 6). Cells were then challenged with $70 \mathrm{~mm} \mathrm{~K}^{+}$with or without PDBu. $, 70 \mathrm{mM} \mathrm{K}^{+} . \square, 70$ $\mathrm{mM} \mathrm{K} \mathrm{K}^{+}+\mathrm{PDBu}(1 \mu \mathrm{M})$. Some cells were treated with $4 \alpha \mathrm{PDD}(1 \mu \mathrm{M})$ rather than PDBu for $24 \mathrm{hr}$ and then stimulated with $70 \mathrm{~mm} \mathrm{~K}^{+}$with $(\triangle)$ or without $(\Delta)$ PDBu $(1 \mu \mathrm{M})$. A further group of cells was treated with TPA $(1 \mu \mathrm{M})$ rather than PDBu for $24 \mathrm{hr}$ and then stimulated with $70 \mathrm{~mm} \mathrm{~K}^{+}$with $(\diamond)$ or without $(\diamond)$ TPA $(100 \mathrm{nM})$. Points are means of 4 incubations.

magnitude of this decrease varied somewhat from experiment to experiment, but could be as great as $60-70 \%$ (e.g., Fig. 5). The ability of chronic phorbol ester treatment to decrease transmitter release was dose-dependent, occurring over the same concentration range as the ability to down regulate PKC (Fig. 5).

We ran several control experiments to investigate issucs that could possibly complicate the interpretation of these data. The first concerned the ability to wash out the phorbol ester. Thus, following chronic phorbol ester treatment we wished to remove the drug, which would yield a preparation of PKC-deficient cells that was not drug-contaminated. We investigated this by examining the washout of ${ }^{3} \mathrm{H}-\mathrm{PDBu}$ after treatment of cells with concentrations similar to those used for down regulation. Figure 6 shows that virtually all the PDBu could be removed by washing. This was also demonstrated using a "functional" assay (Table 1). Cells were challenged with $70 \mathrm{mM} \mathrm{K} \mathrm{K}^{+}$to produce ${ }^{3} \mathrm{H}-\mathrm{NE}$ release. Following a wash period, a second challenge with 70 $\mathrm{mM} \mathrm{K} \mathrm{K}^{+}$produced a second phase of ${ }^{3} \mathrm{H}-\mathrm{NE}$ release. Phorbol

\section{Table 1. Effect of washout on PDBu stimulation of NE release from} PC12 cells

\begin{tabular}{lllll}
$\begin{array}{l}\text { First } \\
\text { release }\end{array}$ & $\begin{array}{l}{ }^{3} \mathrm{H}-\mathrm{NE} \\
\text { released } \\
(\%)\end{array}$ & $\begin{array}{l}\text { Wash } \\
\text { (4 for } 15 \\
\text { min) }\end{array}$ & $\begin{array}{l}\text { Second } \\
\text { release }\end{array}$ & $\begin{array}{l}{ }^{3} \mathrm{H}-\mathrm{NE} \\
\text { released } \\
(\%)\end{array}$ \\
\hline None & 17.9 & None & None & 14.6 \\
None & 18.5 & None & $1 \mu \mathrm{M}$ PDBu & 21.23 \\
$1 \mu \mathrm{M} \mathrm{PDBu}$ & 27.9 & None & None & 14.4 \\
$1 \mu \mathrm{M} \mathrm{PDBu}$ & 28.5 & None & $1 \mu \mathrm{M} \mathrm{PDBu}$ & 19.4
\end{tabular}

$\overline{\mathrm{PC} 12 \text { cells were stimulated to release }{ }^{3} \mathrm{H}-\mathrm{NE} \text { using } 70 \mathrm{mM} \mathrm{K}{ }^{+} \text {with or without }}$ $\mathrm{PDBu}$, as indicated. Between the first and second release stimulations, cells were incubated 4 times for 15 min each in incubation buffer containing $1 \%$ fatty acidfree BSA.

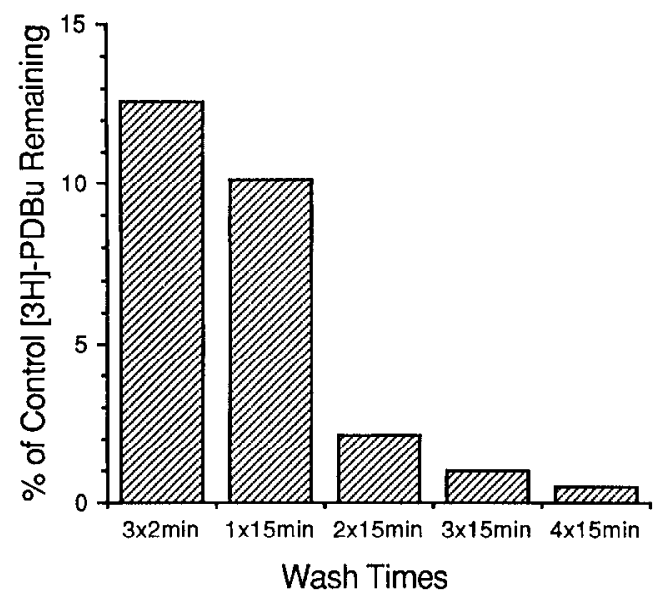

Figure 6. Washout of $\mathrm{PDBu}$ from $\mathrm{PC} 12$ cells. Cells were labeled with ${ }^{3} \mathrm{H}-\mathrm{PDBu}(1 \mu \mathrm{M})$ for $2 \mathrm{hr}$, rinsed 3 times, and then washed with PDBufree incubation medium containing $1 \%$ fatty acid-free BSA for the times indicated.

esters added with either the first or second $70 \mathrm{~mm} \mathrm{~K} \mathrm{~K}^{+}$challenge enhanced release, as compared to control. If phorbol ester were added with the first $70 \mathrm{~mm} \mathrm{~K} \mathrm{~K}^{+}$challenge and the cells were then thoroughly washed, subsequent phorbol ester addition could still clearly augment the second $70 \mathrm{~mm} \mathrm{~K} \mathrm{~K}^{+}$challenge. This would presumably not be the case if the drug remained in the cells following the first challenge, as the cells would already be "augmented."

We and others have also previously shown that upon differentiation with NGF, PC12 cells release less ${ }^{3} \mathrm{H}-\mathrm{NE}$ than do undifferentiated cells (Kongsamut and Miller, 1986). Furthermore, release becomes insensitive to blockade by dihydropyridine drugs, such as nitrendipine. It therefore seemed possible that chronic treatment with phorbol esters was initiating differentiation of the PC12 cells and that this could explain the lower evoked ${ }^{3} \mathrm{H}-\mathrm{NE}$ release. However, as can be seen in Figure 7, following chronic phorbol ester treatment, the release of ${ }^{3} \mathrm{H}-\mathrm{NE}$ from PC12 cells was still blocked by nitrendipine $(1 \mu \mathrm{M})$. This is clearly different from the situation that occurs upon cell differentiation (Kongsamut and Miller, 1986). In conclusion, these experiments demonstrated that down regulation of $\mathrm{PKC}$ following chronic phorbol ester treatment is associated with a loss of the ability of phorbol esters to enhance catecholamine release, and with a reduction in the ability of depolarization to evoke neurotransmitter release.

The decrease in depolarization-induced release of ${ }^{3} \mathrm{H}-\mathrm{NE}$ observed following chronic phorbol ester treatment could be due to down regulation of PKC and the consequent lack of its participation in exocytosis. It is also conceivable, however, that chronic drug treatment leads to a long-term inhibition of voltage-dependent $\mathrm{Ca}^{2+}$ influx (Harris et al., 1985; Di Virgilio et al., 1986; Messing et al., 1986). In order to determine if an intracellular site of action was involved, we also examined the effect of phorbol ester treatment on the release of ${ }^{3} \mathrm{H}-\mathrm{NE}$ induced by the $\mathrm{Ca}^{2+}$ ionophore ionomycin (Fig. 8). Nitrendipine was included as well to block any $\mathrm{Ca}^{2+}$ influx through $\mathrm{Ca}^{2+}$ channels. Ionomycin stimulatcd ${ }^{3} \mathrm{H}-\mathrm{NE}$ release both in the presence and absence of extracellular $\mathrm{Ca}^{2+}$, although release was considerably greater in the presence of $\mathrm{Ca}^{2+}$. In either case, ionomycin-induced release was enhanced by phorbol ester. Following chronic phorbol ester treatment and washout, readdition of phorbol 


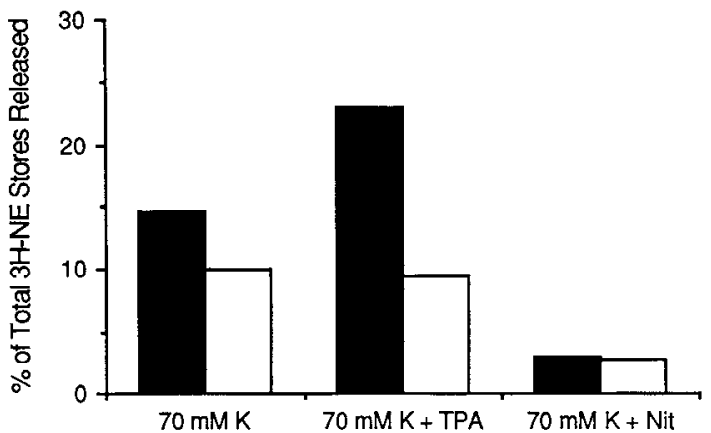

Figure 7. Effect of nitrendipine on $70 \mathrm{mM} \mathrm{K}^{+}$-induced release of ${ }^{3} \mathrm{H}$ NE from PC1 2 cells before and after chronic phorbol ester treatment. Cells were challenged with $70 \mathrm{~mm} \mathrm{~K}{ }^{+}$following culture for $24 \mathrm{hr}$ with $(\square)$ or without $(\square)$ TPA $(1 \mu \mathrm{M})$. Nitrendipine $(N i t ; 1 \mu \mathrm{M})$ was included as indicated. Results are means of 4 separate incubations.

ester no longer enhanced ionomycin-induced release. Furthermore, absolute levels of ionomycin-induced release were reduced below control levels. Thus, the results obtained using ionomycin as a stimulus were comparable to those obtained using depolarization. The data imply that the reduction in the extent of $70 \mathrm{~mm} \mathrm{~K} \mathrm{~K}^{+}$-induced release following chronic phorbol ester treatment is at least partially due to the involvement of $\mathrm{PKC}$ in some aspect of exocytosis rather than to the modulation of $\mathrm{Ca}^{2+}$ entry.

\section{Effects of chronic phorbol ester treatment on cultured rat sympathetic neurons}

We now wished to extend our observations to authentic neurons. We therefore used primary cultures of sympathetic neurons taken from 2-d-old rat pups. These cultures are essentially free of non-neuronal cells (see Materials and Methods). As we have previously demonstrated, depolarizing stimuli evoked release of ${ }^{3} \mathrm{H}-\mathrm{NE}$ from these cells (Perney et al., 1986). We have shown that this evoked release is very sensitive to blockade by $\mathrm{Cd}^{2+}$ or by removal of external $\mathrm{Ca}^{2+}$. As in the case of PC12 cells, we observed that phorbol esters enhanced the $70 \mathrm{mM} \mathrm{K}+$-induced release of ${ }^{3} \mathrm{H}-\mathrm{NE}$ (Fig. 9). Chronic treatment with phorbol esters led to the loss of the phorbol ester-induced enhancement of 70 $\mathrm{mM} \mathrm{K} \mathrm{K}^{+}$-evoked release. Moreover, a large reduction in the percentage of ${ }^{3} \mathrm{H}-\mathrm{NE}$ release evoked by $70 \mathrm{~mm} \mathrm{~K} \mathrm{~K}^{+}$alone was obtained (Fig. 10). These results again parallel those found with PC1 2 cells. We also examined the effect of chronic phorbol ester treatment on PKC activity in sympathetic neurons. Cytosol fractions from these neurons contained PKC of high specific activity. Following chronic phorbol ester treatment, enzyme activity decreased dramatically, essentially to background levels in both the particulate and cytoplasmic fractions (Fig. 11). Chronic drug treatment had little effect on the activities of cAMP-dependent or $\mathrm{Ca}^{2+} /$ calmodulin-dependent protein kinases (Fig. 11). The decline in PKC was also reflected in a reduction of endogenous protein phosphorylation. Untreated sympathetic neurons exhibited a major endogenous $M_{\mathrm{r}} 66,000$ substrate for $\mathrm{Ca}^{2+} /$ phospholipid-stimulated phosphorylation. After chronic drug treatment, incorporation of ${ }^{32} \mathrm{P}$ into this substrate dramatically decreased, substantiating the results obtained using exogenous PKC substrates (data not shown).

\section{Discussion}

The effects of phorbol esters on a wide variety of neuronal processes have aroused a great deal of interest in the potential

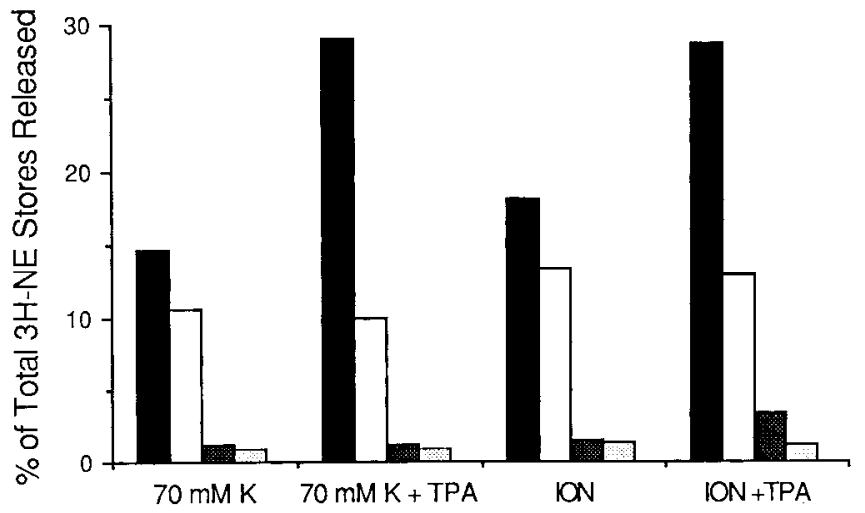

Figure 8. Effect of phorbol esters on ionomycin $(5 \mu \mathrm{g} / \mathrm{ml})$-stimulated ${ }^{3} \mathrm{H}-\mathrm{NE}$ release from $\mathrm{PCl} 2$ cells. Cells were stimulated with either 70 $\mathrm{mm} \mathrm{K}^{+}$or ionomycin in medium containing normal $\mathrm{Ca}^{2+}(1.3 \mathrm{~mm})$ or $0 \mathrm{Ca}^{2+}+50 \mu \mathrm{M}$ EGTA. All ionomycin experiments also contained nitrendipine $(1 \mu \mathrm{M})$ to block any $\mathrm{Ca}^{2+}$ entry via $\mathrm{Ca}^{2+}$ channels. $\mathrm{\square}$, Control $\left(1.3 \mathrm{Ca}^{21}\right) . \square$, Chronic $(24 \mathrm{hr})$ treatment with TPA $(1 \mu \mathrm{M})$ followed by washout of phorbol ester (see Fig. 4). $\mathbf{\square}$, Control $\left(0 \mathrm{Ca}^{2+}\right)$. 图, Chronic $(24 \mathrm{hr})$ treatment with TPA $(1 \mu \mathrm{M})$ followed by washout of phorbol ester (see Fig. 4). Results are means of 4 separate incubations. Total ${ }^{3} \mathrm{H}-\mathrm{NE}$ accumulated was $1.70 \times 10^{5} \pm 2.04 \times 10^{4} \mathrm{cpm} /$ well for control cells and $1.71 \times 10^{5} \pm 1.23 \times 10^{4} \mathrm{cpm} /$ well in TPA-treated cells. Mean \pm SEM for 16 wells.

roles of $\mathrm{PKC}$ in neuronal function. In order to provide further evidence for the participation of PKC in these various activities, it would be advantageous to be able to selectively inhibit the enzyme in intact cells. Ideally this would be achieved pharmacologically, by the use of a specific antagonist. However, no specific blocker of PKC is available at this time. Drugs such as trifluoperazine and polymyxin $\mathrm{B}$ do inhibit $\mathrm{PKC}$, but only in concentrations at which they may interfere with many other cellular functions, including those of other kinases. In the present study, we have demonstrated that PKC-free neuronal cells may be prepared by chronic phorbol ester treatment. As far as can be judged for protein kinase activities, such treatment appears to be specific for PKC. Analysis of cAMP-dependent and $\mathrm{Ca}^{2+} /$ calmodulin-dependent kinases following drug treatment indicated no major changes in the activities of these enzymes.

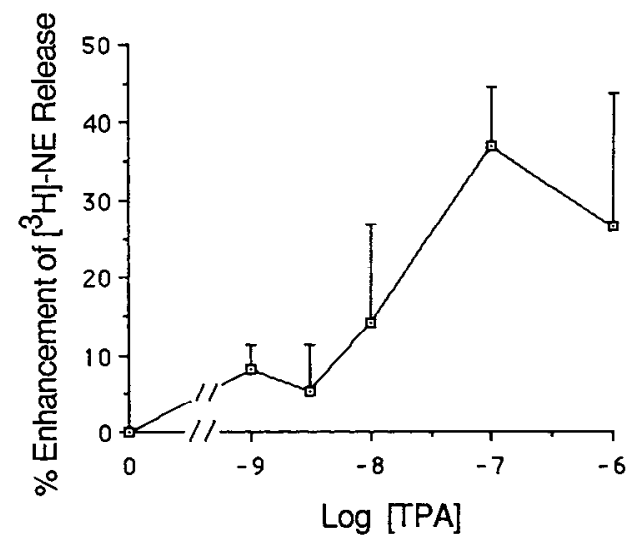

Figure 9. Effect of acute phorbol ester treatment on the $70 \mathrm{~mm} \mathrm{~K} \mathrm{~K}^{+}$ induced release of ${ }^{3} \mathrm{H}-\mathrm{NE}$ from cultures of rat sympathetic neurons. Assays were performed as in Materials and Methods. TPA at the concentrations indicated was added for 10 min prior to the $70 \mathrm{~mm} \mathrm{~K} \mathrm{~K}^{+}$ challenge and also during $70 \mathrm{mM} \mathrm{K} \mathrm{K}^{+}$stimulation. Points represent means \pm SEM for 4 incubations. 


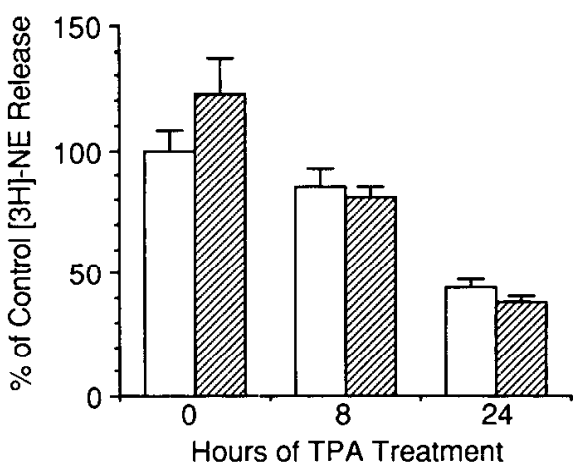

Figure 10. Effect of chronic phorbol ester treatment on $70 \mathrm{mM} \mathrm{K}^{+}$induced ${ }^{3} \mathrm{H}-\mathrm{NE}$ release from cultured rat sympathetic neurons. Cells were treated with TPA $(1 \mu \mathrm{M})$ for the times indicated. The phorbol ester was then washed out (see Figs. 4,6 ) and cells were challenged with 70

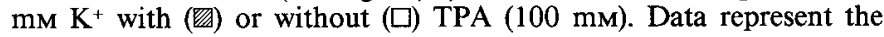
means \pm SEM for 5 incubations.

In addition, both undifferentiated and differentiated PC12 cells and sympathetic neurons appeared perfectly normal and adhered quite normally to the substratum after chronic phorbol ester treatment. Furthermore, undifferentiated PC12 cells appeared to divide at a normal rate.

In most respects, our results for PKC activity resemble those already described for a number of non-neuronal cells when using similar concentrations of phorbol esters (Yamasaki et al., 1980; Jaken et al., 1981; Solanki et al., 1981; Yamasaki et al., 1982; Collins and Rozengurt, 1984; Rodriguez-Pena and Rozengurt, 1984; Ashendel, 1985; Ballester and Rosen, 1985; Palfrey and Waseem, 1985; Wickremansinghe et al., 1985; Fabbro et al., 1986; Glynn et al., 1986). In all of these cases, acute treatment of cells with phorbol esters or a DAG-generating agonist leads to the translocation of PKC from the cytoplasm to the particulate fraction (see also Kraft and Anderson 1983; Wolf et al., 1985; Guy et al., 1986; Liles et al., 1986; McArdle and Conn, 1986). This process occurs over a period of about $15 \mathrm{~min}$. Further treatment with phorbol esters or agonists that activate the enzyme then leads to the deplction of total cellular PKC activity over a period of about 10-20 hr. This effect is seen in most but not all cell types (Ashendel, 1985). In previous studies, dividing cells, such as fibroblasts or tumor lines, have been used. It has been suggested that the ability to down regulate $\mathrm{PKC}$ might be associated with the state of differentiation of the cell, being apparent only in such relatively undifferentiated cases (discussed in Ashendel, 1985). However, we show here that the phenomenon is equally evident in nondividing sympathetic neurons and in differentiated PC12 cells, which divide very slowly. We have also observed similar down regulation of $\mathrm{PKC}$ in primary cultures of rat dorsal root ganglion neurons (unpublished observations).

The biochemical basis for the down regulation of $\mathrm{PKC}$ is unclear at this time, but probably involves proteolysis of the enzyme. Ballester and Rosen (1985) used immunoprecipitation of the enzyme to study the effect of chronic phorbol ester treatment on the fate of radiolabeled $\mathrm{PKC}$ in $\mathrm{GH}_{3}$ pituitary tumor cells. They observed that phorbol ester treatment increased the rate of enzyme removal, presumably because of degradation, at least 20 -fold. It is probable that the activation of PKC and its associated binding to membranes also trigger its degradation. Indeed, a brain protease has been described that cleaves PKC to a $\mathrm{Ca}^{21} /$ phospholipid-independent form, designated "PKM"

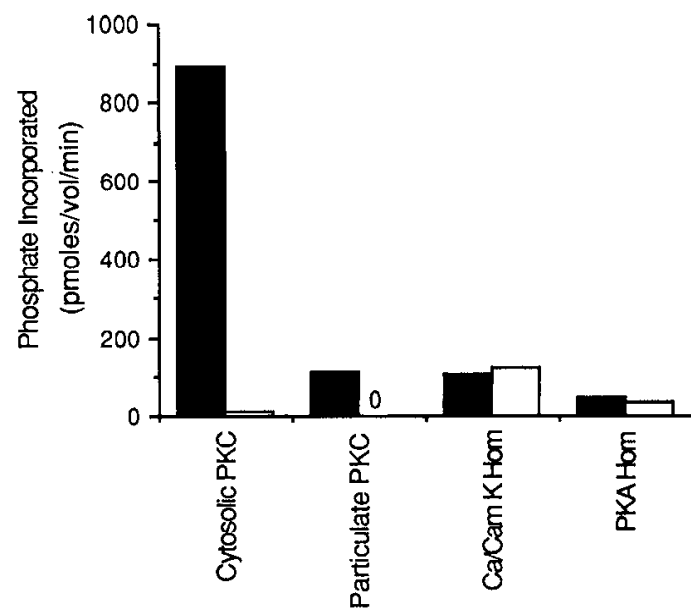

Figure 11. Effect of chronic phorbol ester treatment on the activities of various protein kinases in rat sympathetic neurons. $\mathrm{PKC}$ was assayed in separate cytosolic and particulate fractions. PKA and $\mathrm{Ca}^{2+} / \mathrm{calmodu}-$ lin-dependent kinase activity was assessed in total cell homogenates. $\mathbf{}$, Control. $\square$, TPA $(1 \mu \mathrm{M})$ for $24 \mathrm{hr}$.

(Kishimoto et al., 1983). This protease is stimulated by $\mathrm{Ca}^{2+}$, phospholipid, and DAG. The existence of PKM should be revealed as an increase in $\mathrm{Ca}^{2+}$-independent histone kinase activity in subfractions. However, we did not observe such an increase. Thus, it is possible that $\mathrm{PKC}$ is degraded rapidly to an inactive form in neurons.

One of the suggested roles for PKC in neuronal function is in the regulation of neurotransmitter release. In many cases, phorbol esters can be shown to enhance evoked transmitter release (Pozzan et al., 1984; Harris et al., 1985; Publicover, 1985; Zurgil and Zisapel, 1985; Eusebi et al., 1986). Furthermore, phorbol esters also augment the secretion of products from non-neuronal cells, such as mast cells and most endocrine and exocrine cells (Kojima et al., 1983; Katakami et al., 1984; Koenig et al., 1984; Yamatani et al., 1985; Ronning and Martin, 1986; Shaw and Hanson, 1986; Stutchfield et al., 1986; Takuma and Ichida, 1986; Hishikawa et al., 1985; Turgeon and Waring, 1986). Effects of phorbol esters on transmitter release from neurons do not appear to be due to an enhancement of voltage-sensitive $\mathrm{Ca}^{2+}$ influx (but see Wakade et al., 1986). Indeed, in vertebrate neurons, phorbol esters have been reported to block $\mathrm{Ca}^{2+}$ channels (Rane and Dunlap, 1986). It has been shown that in permeabilized adrenal medullary cells, phorbol esters allow secretion to occur at lower than normal concentrations of $\mathrm{Ca}^{2+}{ }_{\mathrm{i}}(\mathrm{Knight}$ and Baker, 1983; Pocotte et al., 1985). This indicates that the site of phorbol ester-induced augmentation may be 1 or more of the proteins actually involved in vesicle secretion.

In PC12 cells, phorbol esters augment $70 \mathrm{mM} \mathrm{K}^{+}$-evoked ${ }^{3} \mathrm{H}$ $\mathrm{NE}$ release but have virtually no effect in $5 \mathrm{mM} \mathrm{K} \mathrm{K}^{+}$(Harris et al., 1985). We used this phorbol ester effect as a functional assay to monitor the consequences of PKC down regulation. Indeed, at a time corresponding to the commencement of PKC down regulation, the ability of phorbol esters to enhance release was lost, as we had expected. What was unexpected, however, was the observation that as PKC down regulation proceeded further, evoked release declined to levels well below those seen in control cells. The fact that phorbol esters acutely augment evoked catecholamine release and that PKC-deficient cells exhibit a reduced level of depolarization-induced relcasc implics that PKC nor- 
mally participates in the process of stimulus-secretion coupling. It could be supposed that the process of synaptic transmission was altogether too rapid to allow for such an intermediate step. Interestingly, however, depolarization of synaptosomes is associated with increased inositol phospholipid hydrolysis, leading to an increase in diacylglycerol (Kendall and Nahorski, 1985; Gusovsky et al., 1986) and to activation of PKC, as reflected in the $\mathrm{Ca}^{2+}$-dependent stimulation of a specific PKC substrate (Wu et al., 1982). It can be seen from the results reported here that following complete depletion of PKC from PC12 cells or sympathetic neurons, substantial depolarization-evoked secretion still occurs. This PKC-independent process is presumably also regulated by $\mathrm{Ca}^{2+}$ and is conceivably mediated by activation of calmodulin and subsequent stimulation of calmodulindependent kinase(s) (Llinas et al., 1985). In addition, the PKC-dependent and independent pathways may affect different populations of secretory vesicles. Thus, the ability to release 1 population of vesicles might be lost following PKC down regulation. Certain other possible explanations appear less likely. For example, we may be observing the result of a shift in the affinity for $\mathrm{Ca}^{2+}$ of a key component of the release apparatus in PKC-deficient cells. Such a change would be the opposite of the phorbol ester-induced increase in affinity observed in permeabilized adrenal medullary cells (see above) (Knight and Baker, 1983; Pocotte et al., 1985). Also, chronic phorbol ester treatment could lead to a down regulation of $\mathrm{Ca}^{2+}$ channels. However, our results with ionomycin appear to mitigate against this hypothesis and indicate that the site of phorbol ester action in these studies is principally at a point beyond that of $\mathrm{Ca}^{2+}$ entry. Yet another possibility is that chronic phorbol ester treatment prevents the appropriate uptake and storage of ${ }^{3} \mathrm{H}-\mathrm{NE}$ by the cells. Our observations indicate that chronically treated cells take up as much ${ }^{3} \mathrm{H}-\mathrm{NE}$ as control cells (see Fig. 8 legend), but we do not know if this catecholamine is appropriately stored in secretory vesicles. We are currently measuring the absolute pool sizes of stored NE to ascertain if these are modified upon phorbol ester treatment.

We conclude that the most parsimonious interpretation of our data at this time is that PKC is an important element in the neurotransmitter release process. There are clearly similarities between the acute effects of phorbol esters reported here and elsewhere and the increase in transmitter release associated with long-term potentiation in the hippocampus (Malenka et al., 1986a) and in sympathetic ganglia (Briggs et al., 1985; Kuba and Kamamoto, 1986). Indeed, it has been hypothesized that PKC is important in the genesis of this type of synaptic plasticity. The ability to remove $\mathrm{PKC}$ from such neurons could be most helpful in the investigation of this phenomenon.

\section{References}

Akerman, K. E. O., I. G. Scott, and L. C. Andersson (1984) Functional differentiation of a human ganglion cell derived neuroblastoma cell line SH-SY $5 Y$ induced by a phorbol ester (TPA). Ncurochem. Int. 6 : 77-80.

Akers, R. F., D. M. Lovinger, P. A. Colley, D. J. Linden, and A. Routtenberg (1986) Translocation of protein kinase C activity may mediate hippocampal long term potentiation. Science 231: 587-589.

Alkon, D. L., M. Kubota, J. T. Neary, S. Naito, D. Coulter, and H. Rasmussen (1986) C-Kinase activation prolongs $\mathrm{Ca}^{2+}$ dependent inactivation of $\mathrm{K}^{+}$-channels. Biochem. Biophys. Res. Commun. 134 1245-1253.

Ashendel, C. L. (1985) The phorbol ester receptor: A phospholipid regulated protein kinase. Biochem. Biophys. Acta 822: 219-242.

Ballester, R., and O. M. Rosen (1985) Fate of immunoprecipitable protein kinase $\mathrm{C}$ in $\mathrm{GH}_{3}$ cells treated with phorbol-12-myristate-13acetate. J. Biol. Chem. 260: 15194-15199.

Baraban, J. M., S. H. Snyder, and B. F. Alger (1985) Protein kinase $\mathrm{C}$ regulates ionic conductance in hippocampal pyramidal neurones: Electrophysiological effects of phorbol esters. Proc. Natl. Acad. Sci. USA 82: 2538-2542.

Bornstein, M. P. (1958) Reconstituted rat tail collagen used as a substrate for tissue culture on coverslips in maximov slides and roller tubes. Lab. Invest. 4: 134-140.

Briggs, C. A., D. A. McAfee, and R. E. McCaman (1985) Long term potentiation of synaptic acetylcholine release in the superior cervical ganglion of the rat. J. Physiol. (Lond.) 363: 181-190.

Collins, M. K. L., and E. Rozengurt (1984) Homologous and heterologous mitogenic desensitization of Swiss 3T3 cells to phorbol esters and vasopressin: Role of receptor and postreceptor steps. J. Cell. Physiol. 118: 133-142.

De Riemer, S. A., B. Schweitzer, and L. K. Kaczmarek (1985a) Inhibitors of $\mathrm{Ca}^{2+}$ dependent enzymes prevent the onset of afterdischarge in the peptidergic bag cell neurons of Aplysia. Brain Res. 340: 175-180.

De Riemer, S. A., J. A. Strong, K. A. Albert, P. Greengard, and L. K. Kaczmarek (1985b) Enhancement of calcium current in Aplysia neurones by phorbol ester and protein kinase C. Nature 313: 313315.

Di Virgilio, F., T. Pozzan, C. B. Wollheim, L. M. Vicentini, and J. Meldolesi (1986) Tumor promotor phorbol myristate acetate inhibits $\mathrm{Ca}^{2+}$ influx through voltage-gated $\mathrm{Ca}^{2+}$ channel in two secretory cell lines, PC12 and RIN m5F. J. Biol. Chem. 261: 32-35.

Eusebi, F., M. Molinero, and C. G. Caratsch (1986) Effects of phorbol ester on spontaneous transmitter release at the frog neuromuscular junction. Pfluegers Arch. 406: 181-183.

Fabbro, D., R. Regazzi, S. D. Costa, C. Borner, and V. Eppenberger (1986) Protein kinase C densensitization by phorbol esters and its impact on growth of human breast cancer cells. Biochem. Biophys. Res. Commun. 135: 65-73.

Francel, D. C., R. J. Miller, and G. Dawson (1986) Modulation of bradykinin induced inositol triphosphate release in a novel neuroblastoma $\times$ dorsal root ganglion sensory neuron cell line (F-11). J. Neurochem. (in press).

Glynn B., J. W. Colliton, J. M. McDermott, and L. A. Witters (1986) Phorbol esters, but not insulin promote depletion of cytosolic protein kinase $\mathrm{C}$ in rat adipocytes. Biochem. Biophys. Res. Commun. 135: $1119-1125$

Greene, L. A., and A. S. Tischler (1976) Establishment of a noradrenergic clonal line of rat adrenal pheochromocytoma cells which respond to nerve growth factor. Proc. Natl. Acad. Sci. USA 73: 24242428.

Gusovsky, F., E. B. Hollingsworth, and J. W. Daly (1986) Regulation of phosphatidylinositol turnover in brain synaptoneurosome: Stimulatory effects of agents that enhance influx of sodium ions. Proc. Natl. Acad. Sci. USA 83: 3003-3007.

Guy, G. R., J. Gordon, L. Walker, R. H. Michell, and G. Brown (1986) Redistribution of protein kinase $C$ during mitogenesis of human lymphocytes. Biochem. Biophys. Res. Commun. 135: 146-153.

Harris, K. M., S. Kongsamut, and R. J. Miller (1985) Protein kinase $\mathrm{C}$ mediated regulation of calcium channels in PC-12 pheochromocytoma cells. Biochem. Biophys. Res. Commun. 134: 1298-1305.

Hawrot, E., and P. H. Patterson (1979) Long-term culture of dissociated sympathetic neurons. Methods Enzymol. 58: 574-584.

Heidemann, S. R., H. C. Joshi, A. Schecter, J. R. Fletcher, and M. Bothwell (1985) Synergistic effects of cyclic AMP and nerve growth factor on neurite outgrowth and microtubule stability of PC-12 cells. J. Cell Biol. 100: 916-927.

Hidaka, H., M. Inagaki, S. Kawamoto, and Y. Sasaki (1984) Isoquinolinesulfonamides, novel and potent inhibitors of cyclic nucleotide dependent protein kinase and protein kinase C. Biochemistry 23: 5036-5041.

Hishikawa, R., M. Fukase, T. Yamatani, S. Kadowaki, and T. Fujita (1985) Phorbol ester stimulates calcitonin secretion synergistically with A23187 and additively with cyclic AMP in a rat C-cell. Biochem. Biophys. Res. Commun. 132: 424-429.

Jaken, S., A. H. Tashjian, and P. M. Blumberg (1981) Characterization of phorbol ester receptors and their down regulation in $\mathrm{GH}_{4} \mathrm{C}_{1}$ rat pituitary cells. Cancer Res. 41: 2175-2181.

Katakami, Y., K. Kaibuchi, M. Sawamura, Y. Takai, and Y. Nishizuka (1984) Synergistic action of protein kinase $C$ and calcium for his- 
tamine release from rat peritoneal mast cells. Biochem. Biophys. Res. Commun. 121: 573-578.

Kawamoto, S., and H. Hidaka (1984) 1-(5-Isoquinoline sulfonyl)-2methylpiperazine $(\mathrm{H} 7)$ is a selective inhibitor of protein kinase $\mathrm{C}$ in rabbit platelets. Biochem. Biophys. Res. Commun. 125: 258-264.

Kendall, D. A., and S. R. Nahorski (1985) Dihydropyridine calcium channel activators and antagonists influence depolarization evoked inositol phospholipid hydrolysis in brain. Eur. J. Pharmacol. 115: 3136.

Kikkawa, U., Y. Takai, R. Minakuchi, S. Inohara, and Y. Nishizuka (1982) Calcium-activated, phospholipid-dependent protein kinase from rat brain. J. Biol. Chem. 257: 1334l-13348.

Kishimoto, A., N. Kajikawa, M. Shiota, and Y. Nishizuka (1983) Proteolytic activation of calcium-activated, phospholipid-dependent protein kinase by calcium neutral protease. J. Biol. Chem. 258: 11561164.

Knight, D. E., and P. F. Baker (1983) The phorbol ester TPA increases the affinity of exocytosis for calcium ions in "leaky" adrenal medullary cells. FEBS Lett. 160: 98-100.

Koenig, R. J., D. Senator, and P. R. Larsen (1984) Phorbol esters as probes of the regulation of thyrotropin secretion. Biochem. Biophys. Res. Commun. 125: 353-359.

Kojima, I., H. Lippes, K. Kojima, and H. Rasmussen (1983) Aldosterone secretion: Effect of phorbol ester and A23187. Biochem. Biophys. Res. Commun. 116: 555-562.

Kongsamut, S., and R. J. Miller (1986) Nerve growth factor modulates the drug sensitivity of neurotransmitter release from PC-12 cells. Proc. Natl. Acad. Sci. USA 83: 2243-2247.

Kraft, A. S., and W. B. Anderson (1983) Phorbol esters increase the amount of $\mathrm{Ca}^{2+}$, phospholipid-dependent protein kinase associated with membrane. Nature 301: 621-623.

Kuba, K., and E. Kamamoto (1986) Long term potentiation, transmitter release induced by adrenaline in bullfrog sympathetic ganglia. J. Physiol. (Lond.) 374: 515-530.

Liles, W. C., D. D. Hunter, K. E. Meier, and N. M. Nathanson (1986) Activation of protein kinase $C$ induces rapid internalization and subsequent degradation of muscarinic acetylcholine receptors in neuroblastoma cells. J. Biol. Chem. 261: 5307-5313.

Llinas, R., T. L. McGuinness, C. S. Leonard, M. Sugimori, and P. Greengard (1985) Intraterminal injection of Synapsin I or calcium/ calmodulin dependent protein kinase II alters neurotransmitter release at the squid giant synapse. Proc. Natl. Acad. Sci. USA 82: 30353039.

Madison, D. V., R. C. Malenka, and R. A. Nicoll (1986) Phorbol esters block a voltage sensitive chloride conductance in hippocampal pyramidal cells. Nature 321: 695-697.

Malenka, R. C., D. V. Madison, and R. A. Nicoll (1986a) Potentiation of synaptic transmission in the hippocampus by phorbol esters. $\mathrm{Na}$ ture 321: 175-177.

Malenka, R. C., D. V. Madison, R. Andrade, and R. A. Nicoll (1986b) Phorbol esters mimic some cholinergic actions in hippocampal pyramidal neurons. J. Neurosci. 6: 475-480.

Mazzei, G. J., N. Katoh, and J. F. Kuo (1982) Polymyxin B is a more selective inhibitor for phospholipid-sensitive $\mathrm{Ca}^{+2}$-dependent protein kinase than for calmodulin sensitive $\mathrm{Ca}^{+2}$-dependent protein kinase. Biochem. Biophys. Res. Commun. 109: 1129-1133.

McArdle, C. A., and M. P. Conn (1986) Hormone stimulated redistribution of gonadotrope protein kinase C. In vivo dependence on $\mathrm{Ca}^{2+}$ influx. J. Pharmacol. Exp. Ther. 29: 570-576.

Messing, R. O., C. L. Carpenter, and D. A. Greenberg (1986) Inhibition of calcium flux and calcium channel antagonist binding in $\mathrm{PC} 12$ neuronal cell line by phorbol esters and protein kinase C. Biochem. Biophys. Res. Commun. 136: 1049-1056.

Montz, H. P. M., G. E. Davis, S. D. Skaper, M. Manthorpe, and S. Varon (1985) Tumor promoting phorbol diester mimics two distinct neurotrophic factors. Dev. Brain Res. 23: 150-154.

Muldoon, L. L., G. A. Jamieson, A. C. Kao, H. C. Palfrey, and M. L. Villereal (1987) Mechanism for mitogen stimulation of $\mathrm{Na}^{+} / \mathrm{H}^{+} \mathrm{ex}-$ change: Evidence for differential involvement of protein kinase $C$ in two human fibroblast strains. Am. J. Physiol. (in press).

Nishizuka, Y. (1986) Studies and perspective of protein kinase C. Science 233: 305-311.

Pahlman, S., L. Odelstad, E. Larsson, G. Crotte, and K. Nilsson (1981) Phenotypic changes in human neuroblastoma cells in culture induced by $12-O$-tetradecanoyl-phorbol-13-acetate. Int. J. Cancer $28: 583-$ 589.
Palfrey, H. C., and A. Waseem (1985) Protein kinase C in the human erythrocyte. J. Biol. Chem. 260: 16021-16029.

Palfrey, H. C., J. E. Rothlein, and P. Greengard (1983) Calmodulindependent protein kinase and associated substrates in Torpedo electric organ. J. Biol. Chem. 258: 9496-9502.

Perney, T. M., L. D. Hirning, S. E. Leeman, and R. J. Miller (1986) Multiple calcium channels mediate transmitter release from peripheral neurons. Proc. Natl. Acad. Sci. USA 83: 6656-6659.

Pocotte, S. C., R. A. Frye, R. A. Senter, D. R. Terbusch, S. A. Lee, and R. W. Holz (1985) Effects of phorbol ester on catecholamine secretion and protein phosphorylation in adrenal medullary cell cultures. Proc. Natl. Acad. Sci. USA 82: 930-934.

Pozzan, T., G. Gatti, N. Dozio, L. M. Vicentini, and J. Meldolesi (1984) $\mathrm{Ca}^{2+}$ dependent and independent release of neurotransmitters from PC1 2 cells: A role for protein kinase $\mathrm{C}$ activation. J. Cell Biol. 99 628-638.

Publicover, S. J. (1985) Stimulation of spontaneous transmitter release by the phorbol ester $12-O$-tetradecanoylphorbol-13-acetate, an activator of protein kinase C. Brain Res. 333: 185-187.

Rane, S. G., and K. Dunlap (1986) Kinase C activator 1,2-oleoylacetylglycerol attenuates voltage-dependent calcium current in sensory neurones. Proc. Natl. Acad. Sci. USA 83: 184-188.

Rodriguez-Pena, A., and E. Rozengurt (1984) Disappearance of $\mathrm{Ca}^{2+}$ sensitive phospholipid dependent protein kinase activity in phorbol ester treated 3 t 3 cells. Biochem. Biophys. Res. Commun. 120: 10531059.

Ronning, S. A., and T. F. J. Martin (1986) Characterization of phorbol ester and diacylglycerol stimulated secretion in permeabilized $\mathrm{GH}_{3}$ pituitary cells. J. Biol. Chem. 261: 7840-7845.

Shalaby, I. A., S. Kongsamut, S. B. Freedman, and R. J. Miller (1984) The effects of dihydropyridines on neurotransmitter release from cultured neuronal cells. Life Sci. 35: 1289-1295.

Shaw, G. P., and P. J. Hanson (1986) Inhibitory effect of 12-O-tetradecanoylphorbol-13-acetate on acid secretion by rat stomach in vivo. FEBS Lett. 201: 225-230.

Solanki, V., T. J. Slaga, M. Callahan, and E. Hubermann (1981) Down regulation of specific binding of $20^{-3} \mathrm{H}$-phorbol-12,13-dibutyrate and phorbol ester induced differentiation of human promyelocytic leukemia cells. Proc. Natl. Acad. Sci. USA 78: 1722-1725.

Strong, J. A., A. P. Fox, R. W. Tsien, and L. K. Kaczmarek (1986) Phorbol ester promotes a large conductance $\mathrm{Ca}^{2+}$ channel in Aplysia bag cell neurones. Biophys. J. 49: 430 (abstr.).

Stutchfield, J., P. M. Jones, and S. L. Howell (1986) The effects of polymixin $\mathrm{B}$ - a protein kinase $\mathrm{C}$ inhibitor, on insulin secretion from intact and permeabilized islets of Langerhans. Biochem. Biophys. Res. Commun. 136: 1001-1006.

Takuma, T., and T. Ichida (1986) Phorbol ester stimulates amylase secretion from rat parotid cells. FEBS Lett. 199: 53-56.

Toll, L. (1982) Calcium antagonists: High affinity binding and inhibition of calcium transport in a clonal cell line. J. Biol. Chem. 257 . 13189-13192.

Turgeon, J. L., and D. W. Waring (1986) Modification of luteinizing hormone secretion by activators of $\mathrm{Ca}^{2+} /$ phospholipid dependent protein kinase. Endocrinology 118: 2053-2058.

Wakade, A. R., R. K. Malhotra, and T. D. Wakade (1986) Phorbol ester facilities ${ }^{45} \mathrm{Ca}^{2+}$ accumulation and catecholamine secretion by nicotine and excess $\mathrm{K}^{+}$but not by muscarine in rat adrenal medulla. Nature 321: 698-700.

Walter, U., I. Uno, A. Y. C. Liu, and P. Greengard (1977) Identification, characterization, and quantitative measurement of cyclic AMP receptor proteins in cytosol of various tissues using a photoaffinity ligand. J. Biol. Chem. 252: 6494-6500.

Wang, M., A. C. Cahill, and R. C. Perlman (1986) Phorbol-12,13dibutyrate increases tyrosine hydroxylase activity in the superior cervical ganglion of the rat. J. Neurochem. 46: 388-393.

Wickremansinghe, R. G., A. Piga, D. Campana, J. C. Yaxley, and A. U. Hoffbrand (1985) Rapid down regulation of protein kinase C and membrane association in phorbol ester treated leukemia cells. FEBS Lett. 190: 50-55.

Wolf, M., H. Levine, S. May, P. Cuatrecasas, and N. Sahyoun (1985) A model for intracellular translocation of protein kinase $\mathrm{C}$ involving synergism between $\mathrm{Ca}^{2+}$ and phorbol esters. Nature 317: 546-549.

Wooten, M. W., and R. W. Wrenn (1984) Phorbol ester induces intracellular translocation of phospholipid/ $\mathrm{Ca}^{2+}$-dependent protein kinase and stimulates amylase secretion in isolated pancreatic acini. FEBS Lett. $171: 183-186$ 
Wu, W. C. S., S. I. Walaas, A. C. Nairn, and P. Greengard (1982) Calcium plus phospholipid regulates phosphorylation of a $M_{r}$ " $87 \mathrm{~K}$ " substrate protein in brain synaptosomes. Proc. Natl. Acad. Sci. IUSA 79: 5249-5253.

Yamamoto, M., N. W. M. Steinbusch, and T. M. Jessel (1981) Differential properties of identified serotonin neurons in dissociated cultures of embryonic rat brain stem. J. Cell Biol. 91: 142-152.

Yamasaki, H., L. Saint-Vincent, and N. Mantel (1980) Long term effects of a tumor promoter, 12-O-tetradecanoylphorbol-13-acetate on induced differentiation of Friend leukemia cells. Cancer Res. 40: 3780-3785.
Yamasaki, H., C. Drevon, and N. Mantel (1982) Specific binding of phorbol esters to Friend erythroleukemia cells: General properties, down regulation and relationship to cell differentiation. Carcinogenesis, 3: 905-910.

Yamatani, T., S. Kadowaki, T. Chiba, K. Chihara, M. Fukase, and T. Fujita (1985) 12-O-tetradecanoyl-phorbol-13-acetate (TPA) stimulates somatostatin release from isolated perfused rat stomach. Life Sci. 37: 2415-2419.

Zurgil, N., and N. Zisapel (1985) Phorbol esters and calcium act synergistically to enhance neurotransmitter release by brain neurons in culture. FEBS Lett. 185: 257-260. 